\title{
AN OVERVIEW OF THE LEGAL FRAMEWORK OF THE BANKING UNION
}

\author{
Maciej Podgórski
}

\begin{abstract}
The article provides an overview of the legal structure of the Banking Union consisting of two pillars - the Single Supervisory Mechanism and the Single Resolution Mechanism. As a point of departure, it discusses the reasons for the creation of the Banking Union. Then, it analyses the legal structure of the Single Supervisory Mechanism in order to compare it to the legal framework of the Single Resolution Mechanism and shows that the differences in their design are a corollary of disparate legal bases for both instruments. Finally, it argues that the disputed legal basis for the regulation establishing the Single Resolution Mechanism is sufficient in light of Meroni doctrine as formulated in the Short-selling case.
\end{abstract}

Key words: European Union, Banking Union, European Central Bank, Single Supervisory Mechanism, Single Resolution Mechanism

\section{INSTITUTIONAL CONTEXT OF THE BANKING UNION}

The finalisation of the Banking Union is one of the topics currently discussed in the European Union (EU), the significance of which was underlined by President Juncker in his State of the Union Address on 13 September $2017^{1}$, where the head of European Commission identified

Magister prawa (master of Law), College of Inter-Area Individual Studies in the Humanities and Social Sciences, University of Warsaw, m.podgorski@outlook.com.

1 President of the European Commission, "State of the Union Address 2017". November 20, 2018 https://ec.europa.eu/commission/state-union-2017_en: "If we want banks to operate under the same rules and under the same supervision across our continent, then we should encourage all Member States to join the Banking Union. We need to 
the need to supplement already functioning risk-reduction measures by introduction of risk-sharing across the EU banking system, in accordance with the conditions proposed by the Commission in November 2015. The completion of the Banking Union is a subject of broad consensus across the EU Institutions. In the Council Conclusions on a Roadmap to complete the Banking Union from June $2016^{2}$ the Council stipulated the importance of the Banking Union with a view of its completion. A similar call for further action in regard to finalisation of the Banking Union was made by the European Parliament in its Annual Report on Banking Union ${ }^{3}$, where the Parliament reiterated that the Banking Union "remains a pre-requirement for financial stability in the bank-reliant landscape of the European Union" 4 . To this end, an ambitious goal to complete the Banking Union by 2019 was set by the European Commission ${ }^{5}$.

The Commission's objective should be considered in the broader context of the reform of the Economic and Monetary Union - the process initiated by the President of the European Council report titled Towards a Genuine Economic and Monetary Union ${ }^{6}$ (followed by the so-called Four Presidents' Report', as it was issued by the four presidents of the Council, European Commission, European Central Bank and Eurogroup). The

reduce the remaining risks in the banking systems of some of our Member States. Banking Union can only function if risk-reduction and risk-sharing go hand in hand. As everyone well knows, this can only be achieved if the conditions, as proposed by the Commission in November 2015, are met. There can only be a common deposit insurance scheme once everyone will have done their national homework".

2 Council of the European Union, "Press Release 353/16”, 17 June 2016.

3 See: European Parliament resolution of 15 February 2017 on Banking Union Annual Report 2016, 2016/2247(INI).

4 Ibidem at $\mathrm{J}$.

5 European Commission, "Communication to the European Parliament, the Council, the European Central Bank, the European Economic and Social Committee and the Committee of the Regions on completing the Banking Union", COM(2017) 592 final, 11 October 2017.

6 President of the European Council, “Towards a Genuine Economic and Monetary Union, Report of the President of the European Council Herman Van Rompuy”, 25 June 2012. November 20, 2018 https://www.consilium.europa.eu/media/21570/131201.pdf.

7 European Council, "Towards a Genuine Economic and Monetary Union", 5 December 2012. 20 November, 2018 https://www.consilium.europa.eu/uedocs/cms_ Data/docs/pressdata/en/ec/134069.pdf. 
reports contained a road map of actions required to ensure the stability and integrity of the Economic and Monetary Union, established under Article 3(4) of the Treaty on European Union, which was faced with existential challenge during the financial and sovereign debt crises experienced in Europe. Four essential building blocks for the future European and Monetary Union were identified: an integrated financial framework, an integrated budgetary framework, an integrated economic policy framework and strengthened democratic legitimacy and accountability. A particularly strong emphasis was put on ensuring fiscal sustainability and breaking the link, or "a vicious circle" eigns, which was recognized as one of the root causes of the sovereign debt crisis? .

In several Member States the financial crisis of 2007-2008 have spiralled into a vicious circle centred around the interdependence of banks, holding large amounts of debt instruments issued by the governments of their home countries, and their sovereigns. The falling confidence in public finances impacted confidence in the banks, while the banks' vulnerable position resulted in a lack of confidence in public finances, due to the risk of costly bank bail-outs ${ }^{10}$. In the European Central Bank (ECB) Working Paper on Bank exposures and sovereign stress transmission it is noted that "[ $\mathrm{t}]$ he euro-area sovereign debt crisis dramatically spotlighted the nexus between governments and banks and its powerful effects on lending and economic activity: in Greece, Ireland, Italy, Portugal and Spain, the indicators of government and bank default risk spiked together after the Greek bailout in 2010 and then subsided together in 2012 as the ECB committed to buy distressed sovereign debt if necessary" ${ }^{11}$. As it was acknowledged in the Van Rompuy's report, addressing these structural shortcomings was

8 Euro Area Summit Statement, 29 June 2012, p. 1.18 March, 2018 https://consilium.europa.eu/uedocs/cms_data/docs/pressdata/en/ec/131359.pdf.

9 European Council, supra note 7, p. 4.

10 Markus Ehrenpil, Mattias Hector, "Banking Union - What is it?”, Sveriges Riksbank Economic Commentaries, 5(2017), p. 1. 20 November, 2018 https://www.riksbank. se/globalassets/media/rapporter/ekonomiska-kommentarer/engelska/2017/banking-union --what-is-it.pdf.

11 Carlo Altavilla, Marco Pagano, Saverio Simonelli, Bank exposures and sovereign stress transmission, ECB Working Paper Series 1969(2016), p. 2. DOI:http://10.2866/673877. 
"particularly important for the euro area given the deep interdependencies resulting from the single currency"12. Hence, the European Banking Union was designed to remedy the problems made evident during the financial crisis.

In the Communication from the Commission to the European Parliament and the Council ${ }^{3}$ a roadmap towards a Banking Union consisting of two pillars was proposed. The first pillar - common supervision - was to be achieved by the establishment of a Single Supervisory Mechanism (SSM). The second pillar - common crisis management - was to be addressed by a Single Resolution Mechanism (SRM). However, the Five Presidents' Report of 22 June $2015^{14}$ found this two-pillar architecture lacking and proposed a third pillar consisting of a common deposit guarantee scheme "as the current set-up with national deposit guarantee schemes remains vulnerable to large local shocks (...) in particular when the sovereign and the national banking sector are perceived to be in a fragile situation"15. Hence, the Banking Union was supplemented in 2015 by the Commission's proposal ${ }^{16}$ to create a European Common Deposit Insurance Scheme (EDIS) building on the system of national deposit guarantee schemes (DGS) regulated by Directive 2014/49/EU ${ }^{17}$. As of today, only first two pillars were created, while the common system for deposit protection have not yet been established. The SSM became operational in November 2014, and the SRM in January 2016, whilst the

12 President of the European Council, supra note 6, p. 4.

13 European Commission, "Communication to the European Parliament and the Council 'A Roadmap towards a Banking Union”, COM/2012/0510 final, 12 September 2012 .

14 Jeroen Dijsselbloem, Mario Draghi, Jean-Claude Juncker, Martin Schulz, Donald Tusk, "Completing Europe's Economic and Monetary Union”, 22 June 2015. 20 November, 2018 https://ec.europa.eu/commission/sites/beta-political/files/5-presidents-report_ en.pdf.

15 Ibidem, p. 11.

16 European Commission, Communication from the Commission to the European Parliament, the Council, the European Central Bank, the European Economic and Social Committee and the Committee of the Regions "Towards the completion of the Banking Union”, COM/2015/0587 final, 24 November 2017.

17 Directive 2014/49/EU of the European Parliament and of the Council of 16 April 2014 on deposit guarantee schemes, 2014 OJ L 173/149. 
negotiations on the regulation ${ }^{18}$ establishing the EDIS are ongoing within the Council and its preparatory bodies.

Given the recent political impetus for the achievement of a fullyfledged Banking Union and the broad consensus across the EU Institutions in this regard, the establishment of the EDIS seems imminent. This also makes for a good time to review the already completed parts of the Banking Union.

\section{LEGAL FRAMEWORK OF THE FIRST PILLAR OF THE BANKING UNION}

The political impetus for the construction of the Banking Union originated from the Euro Area Summit statement of 29 June 2012 where the heads of state or government of the Eurozone countries invited the Commission to "present Proposals on the basis of Article 127(6) for a single supervisory mechanism shortly" 19 and asked "the Council to consider these Proposals as a matter of urgency by the end of 2012"20. In September 2012 the Commission followed with a proposal for a Council regulation conferring specific tasks on the European Central Bank concerning policies relating to the prudential supervision of credit institutions ${ }^{21}$. The final text of the regulation was approved by the Council in October 2013 and entered into force in November $2013^{22}$. The legal basis for the establishment of the Single Supervisory Mechanism was Article 127(6) of the Treaty on Functioning of the European Union ${ }^{23}$ (TFEU), which provides that,

18 European Commission, Proposal for a regulation of the European Parliament and of the Council amending Regulation (EU) 806/2014 in order to establish a European Deposit Insurance Scheme, COM/2015/0586 final.

19 Euro..., supra note 8, p. 1.

20 Ibidem.

21 European Commission, Proposal for a Council Regulation conferring specific tasks on the European Central Bank concerning policies relating to the prudential supervision of credit institutions, $\operatorname{COM}(2012) 511$ final.

22 Council Regulation (EU) No 1024/2013 of 15 October 2013 conferring specific tasks on the European Central Bank concerning policies relating to the prudential supervision of credit institutions, 2013 OJ L 287/63 (SSM Regulation).

23 Consolidated version of the Treaty on the Functioning of the European Union, 2012 OJ C 326/47 (TFEU). 
"[ $t]$ he Council, acting by means of regulations in accordance with a special legislative procedure, may unanimously, and after consulting the European Parliament and the European Central Bank, confer specific tasks upon the European Central Bank concerning policies relating to the prudential supervision of credit institutions and other financial institutions with the exception of insurance undertakings".

It should be noted that although the EU institutions participating in the legislative process for the SSM Regulation agreed early ${ }^{24}$ on the legal basis for the Single Supervisory Mechanism, there were some doubts in the doctrine as to the appropriateness of Article 127(6) as a legal basis for such an ambitious project, in particular in regard to the broad interpretation of the term "specific tasks" adopted by the legislators. It has been argued by some scholars that "the comprehensive supervisory role entrusted to the ECB under the Single Supervisory Mechanism was not what the drafters of the Maastricht Treaty had in mind when referring to 'specific tasks"" 25 . The issue of proper legal basis was far more problematic for the SRM, as it was made evident during the legislative process for the Single Resolution Mechanism Regulation.

The SSM Regulation was adopted in order to activate the enabling clause of Article 127(6) TFEU and to establish a framework for the exercise of those newly conferred supervisory powers. Under the SSM Regulation the ECB is to exercise its supervisory powers towards individual credit institutions through the Single Supervisory Board (SSB), a separate internal body of the ECB ${ }^{26}$ established under the Single Supervisory Mechanism framework, that would be "primarily responsible for licensing, monitoring and enforcing prudential regulations, such as capital adequacy requirements, liquidity buffers, concentration and leverage limits, and all other prudential requirements under EU law applicable to banks based

24 See: Euro..., supra note 8, p. 1.

25 Bruno De Witte, "Euro crisis responses and the EU legal order: increased institutional variation or constitutional mutation?", European Constitutional Law Review 11 3(2015), p. 441. DOI: https://doi.org/10.1017/S1574019615000292.

26 Article 26 of the SSM Regulation provides that "planning and execution of the tasks conferred on the ECB shall be fully undertaken by an internal body composed of its Chair and Vice Chair". 
in the euro area and other participating EU jurisdictions" 27 . It should be emphasised that the supervisory powers of the SSB are limited to the Member States whose currency is the euro, however the SSM Regulation provides in Article 7 that a Member State whose currency is not the euro may establish a close cooperation between the ECB and the national competent authority of such Member State. Once close cooperation has been established pursuant to Article 7, the Member State becomes a "participating Member State" and falls within the remit of the SSB's prudential supervision. To this day no non-euro country has chosen to join yet, but discussions in Sweden, Denmark and Bulgaria about the possibility to join in are ongoing ${ }^{28}$.

After one-year transition period during which the ECB conducted a comprehensive assessment of all banks falling under its direct supervi$\operatorname{sion}^{29}$ and hired about one thousand individuals to staff the $\mathrm{SSB}^{30}$; the ECB took up its full supervisory tasks in November $2014^{31}$. Although the ECB is exclusively competent to carry out the tasks relating to the prudential supervision conferred upon it by the SSM Regulation "in relation to all credit institutions established in the participating Member States"32, not all credit institutions are placed under the direct supervision of the ECB acting through the Single Supervisory Board. Credit institutions which has been considered "significant" are supervised directly by the SSB, while "less significant" banks are supervised by the national supervisory authorities of participating Member States. The criteria for classifying a bank as "significant" set out in Article 6(4) of the SSM Regulation are following: (1) size, (2) importance for the economy of the Union or any participating Member State, (3) significance of cross-border activities. In any case, if the total value of bank's assets exceeds 30 billion euro or its total assets correspond to at least 20 per cent of the country's GDP, or the country in question and the ECB have agreed to consider the bank to be significant, or the bank has

27 Alexander Kern, "European Banking Union - a legal and institutional analysis of the SSM and the SRM”, European Law Review 40 2(2015), p. 160-161.

28 European Commission, supra note 5, p. 4.

29 Kern, supra note 27, p. 155.

30 Ehrenpil, Hector, supra note 10, p. 2.

31 SSM Regulation, Article 33(2).

32 Ibidem, Article 4(1). 
been subject to support from the European Financial Stability Facility or the European Stability Mechanism, the bank must always be considered significant ${ }^{33}$. The ECB may also, on its own initiative, consider an institution to be of significant relevance even when the conditions above are not met $^{34}$. As of now the ECB directly supervises 118 banks, corresponding to almost 82 per cent of banking assets in the euro area ${ }^{35}$.

Given that the primary objective of the ECB under the Treaty is to maintain price stability ${ }^{36}$, the problem which arose during the legislative process was how to reconcile the ECB's price stability mandate with its new supervisory function. The ECB, as a banking sector supervisor, might be tempted to loosen the monetary policy in order support illiquid or insolvent banks, thereby infringing upon its price stability mandate ${ }^{37}$. Thus, although the Single Supervisory Board is an internal body of the European Central Bank, due to the Germany's insistence on separation of the ECB's prudential supervision function from monetary policy function ${ }^{38}$, the decision was taken to organizationally separate the SSB from the remaining bodies of the ECB. Accordingly, the SSM Regulation in Article 25(2) provides that,

" $[\mathrm{t}]$ he ECB shall carry out the tasks conferred on it by this Regulation without prejudice to and separately from its tasks relating to monetary policy and any other tasks. The tasks conferred on the ECB by this Regulation shall neither interfere with, nor be determined by, its tasks relating to monetary policy".

Moreover, the staff involved in carrying out the supervisory tasks is to be "organisationally separated from, and subject to, separate reporting lines from the staff involved in carrying out other tasks conferred on the

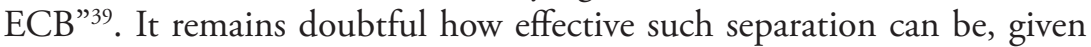

33 Ibidem, Article 6(4).

34 Ibidem.

35 Information obtained from: https://www.bankingsupervision.europa.eu/about/ thessm/html/index.en.html (accessed 22.11.2018).

36 TFEU, Article 127(1).

37 For empirical analysis see: Gerard Hertig, "Central Bank Governance", Swiss Review of Business and Financial Market Law 84 6(2012), pp. 486-493.

38 Kern, supra note 27, p. 165.

39 SSM Regulation, Article 25(2). 
that the SSB's oversight of the SSM is ultimately accountable to the review of the ECB's Governing Council, whose primary objective under the Treaty - maintaining price stability - may be argued to take precedence over the ECB's new mandate of banking supervision ${ }^{40}$. To alleviate this concern the Cyprus Presidency tabled an amendment to the SSM Regulation requiring the chair and vice-chair of the SSB to be appointed by the members of the Economic and Financial Affairs Council participating in the SSM, rather than by the ECB Governing Council as originally proposed $^{41}$. Furthermore, the ECB is required to submit annual reports to the Parliament, which cover, inter alia, the execution of separation between monetary policy and supervisory tasks ${ }^{42}$. All in all, the Single Supervisory Board remains formally an independent body of the ECB, directly accountable to the European Parliament and the Council for the execution of the tasks conferred on the ECB by the SSM Regulation ${ }^{43}$.

\section{LEGAL FRAMEWORK OF THE SECOND PILLAR OF THE BANKING UNION}

Even thought there was no single reason for bank failures during the European sovereign debt $\operatorname{crisis}^{44}$, a substantial support provided to financial institutions since the beginning of the crisis has unduly weighed on public finances and reduced the ability of the Member States to use fiscal policy to stave off the effects of the recession ${ }^{45}$. Since no common European regulatory framework for dealing with failing credit institutions

40 Kern, supra note 27, p. 172.

41 Ibidem.

42 Interinstitutional Agreement between the European Parliament and the European Central Bank on the practical modalities of the exercise of democratic accountability and oversight over the exercise of the tasks conferred on the ECB within the framework of the Single Supervisory Mechanism, 2013/694/EU, 2013 OJ L320/1.

43 SSM Regulation, Article 20.

44 See: Martin F. Hellwig, "Yes Virginia, there is a European Banking Union! But it may not make your wishes come true", MPI Collective Goods Preprint 12(2014), p. 4. DOI:http://dx.doi.org/10.2139/ssrn.2487757.

45 European Council, supra note 7, p. 6. 
was established before the crisis ${ }^{46}$, a brand-new resolution regime had to be created. It should be explained here that the resolution covers all measures taken by a bank resolution authority in order "to resolve problems arising from the exposure to insolvency of (mainly, but not exclusively, systemically important) financial firms (...) and avoid an initiation of liquidation proceedings (thus preventing spillover effects of a bank's failure on the economy) or resort to bail-out measures through public financial assistance facilities" ${ }^{\prime 4}$. A resolution is thus designed to be a specialised regime for bank failures, because, unlike normal insolvency proceedings, its main objective is not the maximisation of creditors value but the preservation of financial stability, the protection of depositors and the minimisation of resort to bail-out through public funds ${ }^{48}$.

\subsection{Establishment of the Single Rulebook}

The first step towards the creation of a common crisis management framework was the Commission's proposal for a directive harmonizing the rules and processes for the resolution of credit institutions ${ }^{49}$ presented in June 2012. The Commission's aim was to "to equip the relevant authorities with common and effective tools and powers to address banking crises preemptively, safeguarding financial stability and minimising taxpayers' exposure to losses" 50 . Despite the Commission's calls for swift action ${ }^{51}$, the final

46 Gianni Lo Schiavo, "The development of a new bank resolution regime in Europe - fit for purpose?", Journal of International Banking Law \& Regulation 29 11(2014), p. 690 .

47 Christos V. Gortsos, "The Single Resolution Mechanism (SRM) and the Single Resolution Fund (SRF): A Comprehensive Overview of the second main pillar of the European Banking Union (Third Edition)", July 31, 2017, p. 29. DOI:http://dx.doi. org/10.2139/ssrn.2668653.

48 Ibidem, p. 30.

49 European Commission, Proposal for a Directive of the European Parliament and of the Council establishing a framework for the recovery and resolution of credit institutions and investment firms and amending Council Directives 77/91 and 82/891, Directives 2001/24, 2002/47, 2004/25, 2005/56, 2007/36 and 2011/35 and Regulation 1093/2010, COM/2012/0280 final (BRRD Proposal).

50 Ibidem, p. 4.

51 European Commission supra note 13. 
text of the Bank Recovery and Resolution Directive ${ }^{52}$ (BRRD) was adopted in April 2014 after a legislative process of almost two years. Shortly after the publication of the BRRD Proposal, the Commission signalled a plan for the creation of the second pillar of the Banking Union - a single resolution mechanism "which would govern the resolution of banks and coordinate in particular the application of resolution tools to banks within the banking union" 53 . The resolution mechanism was closely connected with the BRRD - the directive was meant to be "the single rulebook for the resolution of banks and large investment firms in all EU Member States" 54 , the execution of which was to be ascertained by a common resolution authority. It was contended by the Commission that such mechanism was necessary, since a network of national resolution authorities was not able to efficiently deal with banks "too-big-to-fail" or with cases of cross-border bank failures and even the failure of a relatively small bank may cause cross-border systemic damage ${ }^{55}$ which can destabilize the Eurozone.

\subsection{Proposal for the Single Resolution Mechanism}

In December 2012 presidents of the Council, European Commission, European Central Bank and Eurogroup voiced their support for the SRM built around a single resolution authority, stating that "establishing a single resolution mechanism is indispensable to complete an integrated financial framework" 56 . In particular, they signified the need to break the bank-sovereign nexus, which could be addressed by the single resolution authority able to ensure that the private sector bears the primary burden of

52 Directive 2014/59/EU of the European Parliament and of the Council of 15 May 2014 establishing a framework for the recovery and resolution of credit institutions and investment firms and amending Council Directive 82/891/EEC, and Directives 2001/24/ EC, 2002/47/EC, 2004/25/EC, 2005/56/EC, 2007/36/EC, 2011/35/EU, 2012/30/EU and 2013/36/EU, and Regulations (EU) No 1093/2010 and (EU) No 648/2012, of the European Parliament and of the Council, 2014 OJ L 173/190 (BRRD).

53 European Commission supra note 13.

54 European Commission, "Finalising the Banking Union: European Parliament backs Commission's proposals”, Statement/14/119, 15 April 2014.

55 European Commission supra note 13.

56 European Council, supra note 7, p. 7. 
bank resolution $\operatorname{costs}^{57}$. To this end a European Resolution Fund, financed through ex ante risk-based levies on all the banks directly participating in the SSM, was proposed in the report ${ }^{58}$.

In July 2013, even before the legislative process for the BRRD was finalised, the Commission presented its proposal for the Single Resolution Mechanism ${ }^{59}$. The framework of the Single Resolution Mechanism envisaged by the Commission in the draft regulation was materially altered during the negotiations between co-legislators. According to the initial SRM Proposal, the ECB would identify a bank which is failing or likely to fail and notify the Commission and the Single Resolution Board ${ }^{60}$ consisting of representatives from the Commission ${ }^{61}$, the ECB, and national authorities where the bank operates. The SRB would then make a recommendation on resolution ${ }^{62}$, but the ultimate authority to trigger the bank resolution and to decide on the framework of the resolution tools that shall be applied would lie with the Commission ${ }^{63}$. Once the resolution was triggered the national resolution authorities would implement the approved resolution plan under the supervision of the Single Resolution Board ${ }^{64}$. This initial design of the SRM framework was changed during the legislative process.

\subsection{Evolution of the resolution framework}

In the final text of the Regulation ${ }^{65}$ the first step of the resolution proceedings, the identification of banks which are failing or likely to fail,

57 Ibidem.

58 Ibidem.

59 European Commission, Proposal for a Regulation of the European Parliament and of the Council establishing uniform rules and a uniform procedure for the resolution of credit institutions and certain investment firms in the framework of a Single Resolution Mechanism and a Single Bank Resolution Fund and amending Regulation 1093/2010, $\operatorname{COM}(2013) 520$ final (SRM Proposal).

60 Ibidem, Article 16(1).

61 Ibidem, Article 39(1).

62 Ibidem, Article 16(5).

63 Ibidem, Article 16(6).

64 Ibidem, Article 26(1).

65 Regulation (EU) No 806/2014 of the European Parliament and of the Council of 15 July 2014 establishing uniform rules and a uniform procedure for the resolution of 
and therefore qualify for the supervisory action, remained primarily the role of the ECB acting within the SSM framework ${ }^{66}$. The composition of the Single Resolution Board and its tasks - the main one being drafting resolution schemes based on the analysis of the situation of the bank - was left unchanged. However, the final phase of the process was altered due to considerable opposition from the Germany supported by Sweden and the Czech Republic to the concentration of such broad authority in the Commission $^{67}$. Under the initial proposal the Commission was supposed to decide whether to place a bank under resolution and what tools to use in the resolution plan, but ultimately the role of the Commission was diminished - it would now only be able to either endorse the resolution scheme prepared by the SRB, or object to it with regard to the discretionary aspects of the resolution scheme ${ }^{68}$. The decision on the framework of the resolution tools to be applied was left to the SRB. Moreover, involvement of the Council in the decision-making process was also made possible ${ }^{69}$.

\subsection{Debate on the Single Resolution Fund}

The degree of Commission's discretion in the resolution proceeding was not the only contentious point of the SRM Proposal. There had been also a considerable debate regarding the proposition to establish the Single Resolution Fund (SRF) under Article 114 TFEU. Under the initial proposal of the Commission, the Single Resolution Fund would be created outside of the European Union budget with the objective of ensuring "the effectiveness of the resolution actions, such as providing short term funding to an

credit institutions and certain investment firms in the framework of a Single Resolution Mechanism and a Single Resolution Fund and amending Regulation (EU) No 1093/2010, 2014 OJ L 225/1 (SRM Regulation).

${ }^{66}$ Although the SRB is competent to assess whether the bank is failing or likely to fail, its powers in this regard are limited by Article 18 subparagraph 2 of the SRM Regulation, which dictates that the Board may carry out its own assessment, only after informing the ECB of its intention and only if the ECB, within three calendar days of receipt of that information, does not make such an assessment.

67 Kern, supra note 27, p. 176.

68 SRM Regulation, Article 18(7).

69 Ibidem, Article 18(7-8). 
institution under resolution or guarantees to potential buyers of an institution under resolution" 70 . The SRF would be financed by the contributions collected from the credit institutions in the participating Member States ${ }^{71}$. Some Member States, including Germany, were opposed to the mutualisation of the risk resulting from direct contributions from the banking sector to the SRF. It was argued that delegating the authority to the SRB to administer the Fund ${ }^{72}$ and to decide on the contributions payable, possible borrowing by the Fund, and the use of the Fund's resources in a resolution ${ }^{73}$ would amount to the mutualisation of risk between Member States and was not possible under Article 125(1) TFEU ${ }^{74}$, which states that "the Union shall not be liable for or assume the commitments of central governments, regional, local or other public authorities, other bodies governed by public law, or public undertakings of any Member State".

An alternative solution for the SRF conundrum was proposed by the German officials, whose opposition to the Commission proposal might be attributed to the impending elections to the Bundestag due on 22 September 2013, which at the time had also halted the decision on further Eurozone economic integration ${ }^{75}$. Germany argued that a Single Resolution Fund "could be established and funded by industry contributions along with mutualisation of risks between Member States if these Member States agreed to establish the Fund through an IGA" (Intergovernmental Agreement). Under German pressure, the Commission amended the draft regulation - the SRF was to be established by the SRM Regulation ${ }^{77}$, which would also regulate the SRF governance structure, but an Intergovernmental Agreement would establish the framework for the transfer and progressive mutualisation of the contributions to the Fund. This approach

70 SRM Proposal, Explanatory Memorandum 4.3.1.

71 SRM Proposal, Article 62(1) in connection with Article 2.

72 Ibidem, Article 70(1).

73 Ibidem., Article 71(1).

74 Kern, supra note 27, p. 156.

75 Peter Spiegel, "German politics puts sand in cogs of EU machine”, Financial Times, June 28, 2013. 18 March, 2018 https://www.ft.com/content/74d2d4a4-e007-11e2-9de6$00144 \mathrm{feab} 7 \mathrm{de}$.

76 Kern, supra note 27, p. 177.

77 SRM Regulation, Article 67(1). 
was intended "to provide maximum legal certainty" 78 , given "legal and constitutional concerns in certain member states" 79 .

After a positive legal opinion of the Commission's legal service, according to which "the resort to an IGA under these circumstances was not contrary to the Treaty so long as it was limited to the transfer and mutual-

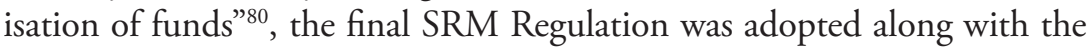
Agreement on the transfer and mutualisation of contributions to the Single Resolution Fund ${ }^{81}$, signed by 26 Member States (all EU countries, except for Sweden and the UK) on 21 May 2014. As of 30 November 2015, a sufficient number of Member States have ratified an intergovernmental agreement on the transfer and mutualisation of contributions to the SRF ${ }^{82}$.

The SRF Agreement, which must be applied and interpreted by the Contracting Parties in conformity with the Treaties and with EU law concerning the resolution of credit institutions (BRRD and SRM Regulation), is applicable only to the Contracting Parties whose institutions are subject to the Single Supervisory Mechanism and the Single Resolution Mechanism $^{83}$. These Contracting Parties are obliged to transfer the contributions raised from credit institutions at national level to the Single Resolution Fund ${ }^{84}$ and to allocate the nationally raised contributions to the different compartments corresponding to each Contracting Party during a transitional period of maximum 8 years ${ }^{85}$. The use of the national compartments shall be "subject to a progressive mutualisation in such a manner that they will cease to exist at the end of transitional period" 86 . The SRF Agreement does not regulate the modalities for the use of the SRF nor the

78 Council of the European Union, “Press Release 10088/14”, 21 May 2014.

79 Ibidem.

80 Kern, supra note 27, p. 177.

81 Council of the European Union, Agreement on the transfer and mutualisation of contributions to the Single Resolution Fund, 8457/14, LIMITE, EF 121, ECOFIN 342. 20 November, 2018 http://register.consilium.europa.eu/doc/srv?l=EN\&f=ST\%20 8457\%202014\%20INIT (SRF Agreement).

82 Information obtained from: http://www.consilium.europa.eu/en/policies/banking-union/single-resolution-mechanism (accessed 20.11.2018).

83 SRF Agreement, Article 1(2).

${ }_{84}$ Ibidem, Article 1(1)(a).

85 Ibidem, Article 1(1)(b).

86 Ibidem. 
general criteria to determine the fixing and calculation the contributions to the Fund, but only the transfer of those contributions from the Member States which remain competent to levy the contributions to the Single Resolution Fund from the entities located in their respective territories. Only taken together the SRM Regulation and the SRF Agreement can provide a complete resolution framework for the credit institutions in the participating Member States.

\subsection{Problematic legal basis for the Single Resolution Mechanism}

Notwithstanding the abovementioned debates regarding the role of the Commission and the make-up of the Single Resolution Fund, the most disputed issue underlying the legislative process for the SRM Regulation was the legal basis for the Single Resolution Mechanism. Whereas in the case of harmonisation of banking supervision by the means of the Single Supervisory Mechanism Article 127(6) TFEU provides an explicit legal basis for the conferral of specific tasks concerning policies relating to prudential supervision of credit institutions and other financial institutions on the European Central Bank, the Treaties do not include any clause enabling a common bank resolution framework. Since the Treaty stipulates that the ECB "can only have supervisory powers conferred on it for individual credit and financial institutions, not wider powers involving bank resolution, nor oversight of financial conglomerates or investment firms" ${ }^{\text {"87, }}$, the resolution powers under the SRM had to be vested in a body outside of the ECB governance structure, preferably in a separate EU agency. Hence, a different legal basis in the Treaty was necessary for the establishment of the second pillar of the Banking Union. As it was already mentioned, the Commission have decided to resort to Article 114 TFEU, which provides a procedure for the achievement of the objectives set out in Article 26 TFEU, that is, for establishing or ensuring the functioning of the internal market. According to Article 114(1) TFEU,

"[t]he European Parliament and the Council shall, acting in accordance with the ordinary legislative procedure and after consulting the Economic and Social Committee, adopt the measures for the approximation of the provisions

${ }^{87}$ Kern, supra note 27, p. 168. 
laid down by law, regulation or administrative action in Member States which have as their object the establishment and functioning of the internal market".

The Commission was of a view that Article 114(1) TFEU is the appropriate legal base, as the SRM Proposal "aims to preserve the integrity and enhance the functioning of the internal market" 88 . The Commission argued that " $[\mathrm{u}]$ niform application of a single set of resolution rules (...) will remove obstacles to the exercise of fundamental freedoms and will avoid significant distortion of competition at least in those Member States which share the supervision of credit institutions at the European level" 89 . This view was challenged by the Member States who claimed that establishment of a new EU agency with wide resolution powers - the Single Resolution Board - does not constitute a measure for the harmonization of the national law and requires a different legal basis ${ }^{90}$. The crux of the argument was whether Article 114 TFEU allows for the transfer of executive powers on a Union agency, especially in light of Meroni doctrine. At the time of negotiations regarding the SRM Proposal, the Court of Justice of the European Union have ruled on the United Kingdom's challenge of one of the powers granted to the European Securities and Markets Authority, an EU agency established on the grounds of Article 114 TFEU. The so called Short-selling case ${ }^{91}$ was an invaluable input into the debate between co-legislators regarding the extent of powers conferred on the Single Resolution Board and the appropriate legal basis for the SRM Regulation. The implications of this case for the Single Resolution Mechanism will be discussed below.

\subsection{Notion of discretionary powers under Meroni doctrine}

As the point of departure, it should be noted that in light of Meroni ${ }^{22}$ a degree of institutional oversight over the exercise of delegated powers by

88 SRM Proposal, Explanatory Memorandum at 3.1.

89 Ibidem.

90 Kern, supra note 27, p. 177.

91 Court of Justice of the European Union, Case C-270/12 United Kingdom v European Parliament, ECLI:EU:C:2014:18.

92 Court of Justice of the European Union, Case 9/56 Meroni v ECSC High Authority, ECR 1957-1958a, p. 133. 
the EU agencies is necessary, since the delegation does not entail an actual transfer of responsibility ${ }^{33}$. The legality of the delegation would not be questioned only if it relates "to clearly defined executive powers, the use of which must be entirely subject to the supervision" ${ }^{\text {"4 }}$ of the delegating authority. However, the early version of Meroni doctrine was revised in the Short-selling case, where the Court found that a direct control of the exercise of delegated powers by the agency is not necessary as long as the exercise of those powers "is circumscribed by various conditions and criteria" 95 which limit the discretion of the agency, by allowing for judicial review of its discretion. It is argued in the doctrine that in Short-selling the complexity of earlier Meroni case law was reduced to the single prohibition of delegating discretionary powers ${ }^{96}$. This new doctrine, which Merijn Chamon calls "Meroni-light", was supplemented by reinterpretation of the notion of "discretionary powers" European Union established that when the powers available to the agency "are precisely delineated and amenable to judicial review in the light of the objectives established by the delegating authority" 98 they should not be considered "discretionary".

Although the rationale behind the softening of the Meroni doctrine is debated in the legal doctrine, there is no doubt that the Lisbon Treaty granted the Court of Justice an explicit competence to review the acts of the EU agencies, what was pointed out by the Court in paragraphs 65 and 80 of the Short-selling ruling. The possibility of the judicial review of those acts could warrant a lack of continuous scrutiny of agencies by the delegating authorities ${ }^{99}$, especially when the very purpose of the establishment

93 Ibidem, p. 152.

94 Ibidem.

95 Court of Justice of the European Union, supra note 91, at para 45.

96 M. Chamon, "The empowerment of agencies under the Meroni doctrine and article 114 TFEU”, European Law Review 39 (3)2014, p. 393.

97 Ibidem.

98 Court of Justice of the European Union, supra note 91, at para 53.

99 The term „delegating authority” is used here to denote any institution established by the constitutional framework of the Treaties, since the Court in Short-selling case does not differentiate between the delegation and the conferral of powers. It is clear that in the case of the SRB the powers are conferred. 
of a new agency is to form an impartial body capable in fields requiring specific technical expertise ${ }^{100}$. Even though, from purely legal point of view the control of legality of decisions adopted by the agencies, could be carried out solely by the Court of Justice of the European Union, provided that the criteria for the exercise of their delegated powers are established in the underlining legislation, this solution might not feasible in the case of SRB. When the resolution of the bank is necessary, a swift and effective decision-making process is of paramount importance for the financial stability of the internal market. Given the workload of the European Union Courts, the judicial review of the SRB's course of action in the 24-hour period provided for the assessment of the resolution scheme ${ }^{101}$ would not be possible. Some degree of involvement of the EU institutions in the decision-making process under the SRM seems to be necessary in order to ensure the balance between the rights of the individuals and the public interest of the European Union. A detailed analysis of the accountability of the decision-making process under the SRM is beyond the scope of this article, however it should be pointed out here that both the Single Rulebook and the SRM Regulation provide a set of criteria for the exercise of the executive powers by the SRB, which are no more general or vague than the criteria sanctioned by the Court in the Short-selling case ${ }^{102}$. Hence, the powers conferred on the SRB in the SRM Regulation should not be considered discretionary in the light of revised Meroni doctrine.

\subsection{Legal basis conundrum in light of the Short-selling judgement}

In the Short-selling case the Court formulated two requirements for a legislative act to be lawfully adopted on the grounds of Article 114 TFEU. Such an act must "first, comprise measures for the approximation of the provisions laid down by law, regulation or administrative action in the Member States and, second, have as its object the establishment and functioning of the internal market" ${ }^{\prime 103}$. The Court explained that by

\footnotetext{
${ }^{100}$ Court of Justice of the European Union, supra note 91, at paras 72 and 82.

101 SRM Regulation, Article 18(7).

102 Chamon, supra note 96, p. 402.

${ }^{103}$ Court of Justice of the European Union, supra note 91, at para 100.
} 
expression "measures for the approximation", "the authors of the FEU Treaty intended to confer on the Union legislature, depending on the general context and the specific circumstances of the matter to be harmonised, discretion as regards the most appropriate method of harmonisation for achieving the desired result, especially in fields with complex technical features" ${ }^{104}$. Considering the systemic nature of financial regulations, it is clear that the area of financial supervision must be regarded as a "field with complex technical features". Moreover, it is apparent from recital 4 in the preamble to SRM Regulation that the competent authorities of various Member States have adopted national resolution rules. It is also pointed out in recital 2 that the measures adopted by Member States and their corresponding administrative practices are divergent as the European Union lacks a specific common regulatory framework for resolution of credit institutions and certain investment firms, what warrants a harmonization of the resolution regimes across the EU. There is also no doubt that "the uniform application of the resolution regime in the participating Member States will be enhanced as a result of it being entrusted to a central authority such as the SRM"105. Thus, the objective of the SRM Regulation was not intended to introduce completely new EU-wide resolution framework, but to harmonise already existing national rules and procedures in this field, hence the first criterion established by the Court in Short-selling case is fulfilled.

With regard to the second criterion, it should be underlined that, although the SRM Regulation focuses on the internal market for banking services - the functioning of which was threatened by the increasing risk of financial fragmentation due to the ongoing financial and economic crisis - a directly applicable set of uniform rules governing the resolution procedure provided for in the SRM Regulation would be beneficial to the whole internal market as it will "contribute to ensuring fair competition and to preventing obstacles to the free exercise of fundamental freedoms"106. It follows that the purpose of the Regulation in question is in fact to improve the conditions for the establishment and functioning of the internal market,

\footnotetext{
104 Ibidem at para 102.

105 SRM Regulation, Recital 11.

106 Ibidem, Recital 21.
} 
in particular, in the field of financial services ${ }^{107}$. Since both criteria set out in the paragraph 100 of the Short-selling ruling are met, Article 114 TFEU should be considered a sufficient legal basis for the SRM Regulation.

As regards the creation of the Single Resolution Board, taking into account the wide margin of discretion granted to the EU legislature when it comes to choosing the most appropriate method of harmonisation for achieving the desired results in fields where complex technical analysis is required, the establishment of the SRB in the SRM Regulation should be considered to be an appropriate measure for the approximation of national legal provisions. In Short-selling the Court made clear that the EU legislature is competent, whenever deemed necessary, to establish "an EU body responsible for contributing to the implementation of a process of harmonisation" 108 . In the same ruling the Court also pointed out that "the EU legislature, in its choice of method of harmonisation and, taking account of the discretion it enjoys with regard to the measures provided for under Article 114 TFEU, may delegate to a Union body, office or agency powers for the implementation of the harmonisation sought" 109 . This applies in particular "where the measures to be adopted are dependent on specific professional and technical expertise and the ability of such a body to respond swiftly and appropriately" ${ }^{110}$. In the context of the SRM Regulation, it should be clear that the creation of the Single Resolution Board was a prerequisite for the achievement of the goal of the Regulation. According to recital 31 in the preamble to the SRM Regulation, in order to ensure "a swift and effective decision-making process in resolution, the Board should be a specific Union agency with a specific structure, corresponding to its specific tasks" - only such specialized agency can effectively monitor the situation of credit institutions in order to avoid future bailouts. In this regard, it should be noted that the EU legislature conceded that a supranational supervisor is better equipped to deal with the failing credit institutions, as national supervisors often have strong incentives to minimise the potential negative impact of bank failure on their national

107 See: Chamon, supra note 96, p. 401.

${ }_{108}$ Court of Justice of the European Union, supra note 91, at para 104.

${ }^{109}$ Ibidem at para 105.

${ }^{110}$ Ibidem. 
economies ${ }^{111}$, what may prevent them from taking necessary resolution action. Such behaviour of national regulators may constitute a threat not only to the national banking system, but also the to the orderly functioning of the financial market of the Union. The EU legislature also indicated, at recital 10 in the preamble to SRM Regulation, that it is appropriate and necessary for the rules provided for in the regulation to take the legislative form of a regulation, as the minimum harmonisation of rules relating to the resolution provided in the BRRD is not sufficient for ensuring effective resolution for failing banks within the European Union. Hence, the establishment of the Single Resolution Board was deemed to be "an integral part of the process of harmonisation in the field of resolution operated by Directive 2014/59/EU and by the set of uniform provisions on resolution laid down in this Regulation"112.

Considering the arguments stated above, it is clear that, in light of the Short-selling case, the creation of the Single Resolution Mechanism, including the Single Resolution Board, may be qualified as an approximation measure under Article 114 TFEU. Moreover, the transfer of executive powers on the SRB should be considered permissible in the light of revised Meroni doctrine. This position was also shared by the EU co-legislators who, after the publication of the judgement in the Short-selling case, agreed to adopt the SRM Regulation on the grounds of Article 114 TFEU. The final text of the regulation was published on 15 July 2014, just two months after the publication of the Bank Recovery and Resolution Directive. Pursuant to the Article 99 of the SRM Regulation the Single Resolution Board became fully operational on the 1 January $2016^{113}$, when it took over full responsibility for bank resolutions within the Banking Union. The creation of the Single Resolution Fund is still ongoing - the Fund will be gradually built up during the first eight years, starting from 1 January 2016, and shall reach the target level of at least $1 \%$ of the amount of covered deposits of all credit institutions authorised in all of the participating Member States by 31 December $2023^{114}$.

\footnotetext{
111 SRM Regulation, Recital 9.

112 Ibidem, Recital 11.

${ }^{113}$ European Commission, Press Release IP/15/6397, 31 December 2015.

114 SRM Regulation, Article 69(1).
} 


\section{CONCLUSION}

From the analysis presented above it is clear that the most significant differences between the legal frameworks of the Single Supervisory Mechanism and the Single Resolution Mechanism result from distinctive legal bases for their creation. Contrary to the Single Supervisory Board, which due to the formulation of the enabling clause in Article 127(6) TFEU had to be established within the internal governance structure of the European Central Bank, the Single Resolution Board was set up as an independent agency on the grounds of Article 114 TFEU. Although there are plenty arguments in favour of the use of Article 114 TFEU to establish the $\mathrm{SRM}^{115}$, the soundness of this legal basis was questioned due to the existence of Meroni doctrine. These concerns are unfounded because of the recent revision of this doctrine in Short-selling case, where the Court has also established the criteria for a legislative act to be lawfully adopted on the grounds of Article 114 TFEU. As it was argued in this article, the requirements set out by the Court are met in the case of the SRM Regulation.

\section{REFERENCES}

Altavilla, Carlo, Marco Pagano, Saverio Simonelli, 2016, "Bank exposures and sovereign stress transmission”, ECB Working Paper Series 1969 (2016): 1-64. DOI:http://10.2866/673877.

Chamon, Merijn, 2014, "The empowerment of agencies under the Meroni doctrine and article 114 TFEU”, European Law Review 39 (3)2014: 380-403.

De Witte, Bruno, 2015, "Euro crisis responses and the EU legal order: increased institutional variation or constitutional mutation?", European Constitutional Law Review 11 3(2015):434-457. DOI: https://doi.org/10.1017/ S1574019615000292..

Dijsselbloem, Jeroen, Mario Draghi, Jean-Claude Juncker, Martin Schulz, Donald Tusk, 2018, "Completing Europe's Economic and Monetary Union", 22 June 2015. 20 November, 2018 https://ec.europa.eu/commission/sites/ beta-political/files/5-presidents-report_en.pdf.

115 See: Lo Schiavo, supra note 46, p. 698. 
Ehrenpil, Markus, Mattias Hector, 2017, “Banking Union - What is it?”, Sveriges Riksbank Economic Commentaries, 5 (2017): 1-8. 20 November, 2018 https://www.riksbank.se/globalassets/media/rapporter/ekonomiska-kommentarer/engelska/2017/banking-union--what-is-it.pdf.

Gortsos, Christos V., 2017, "The Single Resolution Mechanism (SRM) and the Single Resolution Fund (SRF): A Comprehensive Overview of the second main pillar of the European Banking Union (Third Edition)", July 31, 2017. DOI:http://dx.doi.org/10.2139/ssrn.2668653.

Hellwig, Martin F., 2014, "Yes Virginia, there is a European Banking Union! But it may not make your wishes come true", MPI Collective Goods Preprint 12 (2014): 1-29. DOI:http://dx.doi.org/10.2139/ssrn.2487757.

Hertig, Gerard, 2012, "Central Bank Governance", Swiss Review of Business and Financial Market Law 846 (2012): 486-493.

Kern, Alexander, 2015, "European Banking Union - a legal and institutional analysis of the SSM and the SRM", European Law Review 402 (2015): 154-187. Lo Schiavo, Gainni, 2014, "The development of a new bank resolution regime in Europe - fit for purpose?”, Journal of International Banking Law \& Regulation 2911 (2014): 689-704.

Spiegel, Peter, 2018, "German politics puts sand in cogs of EU machine", Financial Times, June 28, 2013. 18 March, 2018 https://www.ft.com/ content/74d2d4a4-e007-11e2-9de6-00144feab7de. 